\title{
ANALISIS PENGARUH PERUBAHAN VARIABEL MAKROEKONOMI TERHADAP RETURN SAHAM SYARIAH PT. TELEKOMUNIKASI INDONESIA, TBK. PERIODE 2011-2013
}

\author{
Siti Sunayah, Zaini Ibrahim \\ IAIN Sultan Maulana Hasanuddin Banten
}

\begin{abstract}
Abstrak. Analisis Pengaruh Perubahan Variabel Makroekonomi Terhadap Return Saham Syariah PT. Telekomunikasi Indonesia, Tbk. Periode 2011-2013. Variabel makroekonomi yang dimaksud dalam penelitian ini meliputi nilai tukar rupiah, suku bunga dan inflasi. Ketiga variabel makroekonomi tersebut dicoba diukur pengaruhnya terhadap tingkat return saham syariah dari PT. Telekomunikasi Indonesia, tbk. selama periode 2011-2013. Data kurs, inflasi, dan suku bunga diperoleh dari situs Bank Indonesia (BI), dan data return saham syariah PT. Telekomunikasi Indonesia diambil dari situs Bursa Efek Indonesia (BEI) serta dari situs Bank Indonesia (BI). Alat analisis yang digunakan yaitu regresi linier berganda dengan bantuan software eviews 7. Hasil yang diperoleh menyatakan semua variabel bebas tidak berpengaruh terhadap variabel terikat secara parsial (sendiri-sendiri), namun secara simultan (bersama-sama) ketiga variabel bebas berpengaruh terhadap variabel terikat. Dengan toleransi kesalahan sebesar 5\% nilai tukar rupiah, suku bunga dan inflasi mampu menjelaskan perubahan return saham syariah PT. Telekomunikasi Indonesia, Tbk sebesar 8,6\%. Setiap peningkatan nilai tukar rupiah sebesar 1\% akan menaikan besarnya return PT. Telekomunikasi Indonesia, Tbk sebanyak 1,76\%, sedangkan setiap peningkatan suku bunga sebesar $1 \%$ akan menaikan return saham syariah PT. Telekomunikasi Indonesia, Tbk sebanyak 31,4\%, selanjutnya setiap peningkatan inflasi sebesar 1\% akan menaikan return saham syariah PT. Telekomunikasi Indonesia, Tbk sebanyak 0,086\%. Dengan demikian, variabel bebas yang lebih dominan terhadap return saham PT. Telkom adalah suku bunga perbankan.
\end{abstract}

Kata Kunci: nilai tukar, bunga, inflasi, efek, return, saham syariah.

Abstract. Analysis on Effect of Changes in Macroeconomic Variables Return against Sharia Stock at PT. Telekomunikasi Indonesia, Tbk. 2011-2013. Macroeconomic variables used in this study is the exchange rate, interest rates and inflation. These variables tried measurable macroeconomic impact on the level of sharia stock returns from PT. Telekomunikasi Indonesia, Tbk. during 2011-2013. The data of exchange rate, inflation, and interest rates obtained from the site of Bank Indonesia (BI), and the data of sharia stock returns PT. Telekomunikasi Indonesia from the site of Indonesia Stock Exchange (BEI) as well as on the site of Bank Indonesia (BI). The instrument used in this research is multiple linear regression and software eviews 7 . The results obtained that all independent variables have no effect on the dependent variable partially (alone), but simultaneously (together) three independent variables affect the dependent variable. With fault tolerance of 5\% exchange rate, interest rates and 
Islamiconomic: Jurnal Ekonomi Keuangan dan Bisnis Islam

Vol.7 No.1 Januari - Juni 2016

$\overline{\text { inflation are able to explain changes in stock return of sharia PT. Telekomunikasi }}$ Indonesia, Tbk amounted to $8.6 \%$. Every increase in the exchange rate of $1 \%$ would increase the amount of return PT. Telekomunikasi Indonesia, Tbk as much as $1.76 \%$, whereas any increase in interest rates by $1 \%$ will increase the stock return of sharia PT. Telekomunikasi Indonesia, Tbk as much as 31.4\%, then any increase in inflation of $1 \%$ would raise the stock return of sharia PT. Telekomunikasi Indonesia, Tbk as much as $0.086 \%$. Thus, the independent variables are more dominant on stock returns PT. Telkom is in bank interest rates.

Keywords: Exchange rate, interest, inflation, effects, returns, Islamic stocks.

\section{Pendahuluan}

Sistem keuangan di dunia saat ini berada di persimpangan jalan yang disebabkan oleh krisis keuangan tahun 2008 yang dipicu oleh kasus subprime mortrage. Kasus tersebut mendorong berbagai intervensi pemerintah melalui bailout, suntikan modal, penutupan, akuisisi, dan pemberian stimulus untuk mendorong ekonomi yang stagnan atau terkontraksi. ${ }^{1}$ Krisis keuangan global tersebut mempengaruhi kinerja keuangan perusahaan-perusahaan di Indonesia, sehingga mempengaruhi investor untuk berinvestasi di pasar modal, khususnya pada suratsurat berharga. Dalam skala makro, hal ini dapat mengakibatkan melambatnya pertumbuhan ekonomi yang disebabkan penurunan nilai investasi yang merupakan penggerak perekonomian negara.

Pasar modal memiliki peran strategis dalam perekonomian modern, sehingga pasar modal disebut juga sebagai indikator utama perekonomian negara (leading indicator of economy). ${ }^{2}$ Bila orang menilai keadaan perekonomian suatu negara, maka dia akan melihat juga perkembangan indeks harga saham, di samping angka inflasi, neraca transaksi berjalan, dan pertumbuhan PDB (Produk Domestik Bruto). ${ }^{3}$

Di era modern, perdagangan yang berlangsung tidak hanya menjualbelikan aset-aset riil tetapi juga aset-aset keuangan berupa surat-surat berharga (sekuritas). ${ }^{4}$ Perdagangan beberapa jenis sekuritas, baik pada pasar modal konvensional maupun pasar modal syariah mempunyai tingkat return dan risiko yang berbeda. Saham merupakan bukti kepemilikan seseorang atau pemegang saham atas aset perusahaan. ${ }^{5}$ Saham adalah salah satu sekuritas diantara sekuritas-sekuritas lainnya yang mempunyai tingkat risiko yang tinggi. Risiko tinggi tersebut dikarenakan adanya ketidak pastian return yang diterima investor di masa yang akan datang. Sebenarnya, return dan risiko sacara teoritis mempunyai hubungan yang positif. 
Siti Sunayah, Zaini Ibrahim: Analisis Pengaruh Perubahan...

Semakin besar return yang diterima, maka semakin besar risiko yang diperoleh, begitupun sebaliknya. Return dan risiko yang tinggi pada saham saling berhubungan dengan kondisi ekonomi makro, industri dan karakteristik perusahaan.

Di Indonesia, indeks Islam dikenal dengan Jakarta Islamic Index (JII). Indeks tersebut dikeluarkan oleh Bursa Efek Indonesia (BEI), dimana ada 30 Emiten yang terdaftar dalam JII. JII akan dikaji setiap 6 bulan dengan penentuan komponen index pada awal bulan Januari dan Juli setiap tahunnya. ${ }^{6}$ Perkembangan pasar modal syariah tumbuh sangat baik, seiring dengan meningkatnya indeks yang terdaftar dalam Jakarta Islamic Indeks (JII). ${ }^{7}$ Peningkatan indeks pada JII walaupun nilainya tidak sebesar pada Indeks Harga Saham Gabungan (IHSG) tetapi kenaikan secara prosentase indeks pada JII lebih besar dari IHSG. Hal ini dikarenakan adanya konsep halal, berkah dan bertambah pada pasar modal syariah yang memperdagangkan saham syariah.

Dari uraian singkat di atas, penulis tertarik melakukan penelitian dengan perumusan masalah sebagai berikut:

1. Apakah nilai tukar rupiah, suku bunga dan inflasi berpengaruh terhadap return saham syariah PT. Telekomunikasi Indonesia, Tbk?

2. Berapa besar pengaruh nilai tukar rupiah, suku bunga dan inflasi terhadap return saham syariah PT. Telekomunikasi Indonesia, Tbk?

3. Berapa perubahan return saham syariah ketika nilai tukar rupiah, suku bunga dan inflasi berubah sebesar 1\%?

Objek penelitian dalam penelitian ini adalah saham perusahaan yang muncul berturut-turut selama 3 tahun dalam daftar JII yaitu PT. Telekomunikasi Indonesia tbk (persero) (selanjutnya disingkat PT Telkom). Rentang data penelitian yaitu periode 2011 sampai 2013.

\section{Kerangka Pemikiran}

Pasar modal adalah tempat pertemuan dan melakukan transaksi antar pencari dana (emiten) dan para penanam modal (investor). ${ }^{8}$ Jakarta Islamic Indeks merupakan indeks terakhir yang dikembangkan oleh BEI bekerja sama dengan Danareksa Investment Management. Indeks syariah merupakan indeks berdasarkan syariah Islam. Pasar modal syariah kini mendapatkan momentum untuk tumbuh di 
Islamiconomic: Jurnal Ekonomi Keuangan dan Bisnis Islam

Vol.7 No.1 Januari - Juni 2016

pasar, khususnya untuk pasar yang berkembang di kawasan Timur Tengah, Asia Tenggara, Asia Selatan dan Afrika Utara. ${ }^{9}$

Penerapan prinsip syariah di pasar modal tentunya bersumber pada Al Quran dan Hadits. Dari kedua sumber hukum tersebut para ulama melakukan penafsiran yang disebut dengan ilmu fiqih. Dalam salah satu pembahasannya adalah mengenai muamalah, yaitu hubungan manusia dengan manusia terkait perniagaan. Terdapat kaidah fiqih muamalah yang menyatakan bahwa semua bentuk muamalah boleh dilakukan kecuali ada dalil yang mengharamkannya, dasar hukumnya adalah ayat berikut:

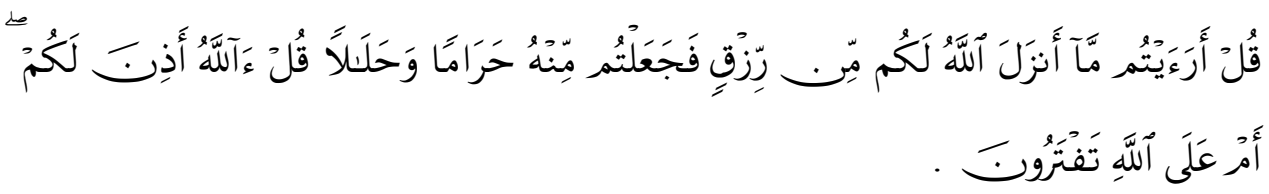

"Katakanlah: "Terangkanlah kepadaku tentang rezki yang diturunkan Allah kepadamu, lalu kamu jadikan sebagiannya Haram dan (sebagiannya) halal". Katakanlah: "Apakah Allah telah memberikan izin kepadamu (tentang ini) atau kamu mengada-adakan saja terhadap Allah ?"(Q.S Yunus: 59).10

Pada dasarnya adalah segala jual beli adalah dibolehkan, maka dalam pasar modal juga demikian adanya, namun yang tidak diperbolehkan dalam penerapan pengumpulan modal melalui jual beli saham dalam pasar modal ini, yaitu tidak boleh ada unsur spekulasi dalam jual beli saham, artinya ketika ada pihak yang membeli dari pihak pertama dengan tujuan untuk dijual lagi ketika harga saham naik pada pihak ketiga dengan tujuan menambah modal, maka terdapat unsur riba didalamnya, karena orang cenderung menjualnya dengan harga tinggi dibanding ketika dia membeli, ini yang tidak di perbolehkan dalam Islam karena mengandung unsur spekulasi dan tidak sesuai akad pertama seperti yang diutarakan pada ayat Alquran berikut:

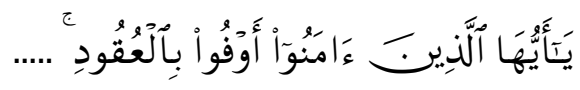

Hai orang-orang yang beriman, penuhilah aqad-aqad itu..." (Q.S Al Maidah :1). ${ }^{11}$

Pemilihan sistem nilai tukar merupakan persoalan besar dalam perekonomian saat ini. ${ }^{12}$ Kurs valuta asing adalah nilai seunit valuta atau mata uang asing apabila ditukarkan dengan mata uang dalam negeri. ${ }^{13}$ Ketidakstabilan nilai tukar rupiah 
Siti Sunayah, Zaini Ibrahim: Analisis Pengaruh Perubahan...

terhadap dollar dari waktu ke waktu menyebabkan ketidakstabilan harga saham. Kondisi ini cenderung menimbulkan keragu-raguan bagi investor, sehingga kinerja bursa efek menjadi menurun. Hal ini dapat dilihat dari harga sekuritas atau harga saham yang sedang terjadi, baik indeks harga saham sektoral maupun Indeks Harga Saham Gabungan. Dalam sistem nilai tukar fleksibel (flexible exchange rate), nilai tukar suatu mata uang sama seperti halnya barang, ditentukan oleh interaksi permintaan dan penawaran. ${ }^{14}$ Valuta asing diistilahkan dengan kata as-sarf yang berarti jual beli valuta asing atau dalam istilah bahasa inggris adalah money changer. Sarf merupakan akad jual beli beli mata uang baik dengan sesama mata uang yang sejenis (misalnya rupiah dengan rupiah) maupun yang tidak sejenis (misalnya rupiah dengan dollar atau sebaliknya). Dasar hukum keabsahan melakukan jual beli uang (Sarf) terdapat dalam Al Qur'an Surat Al Baqarah ayat 275:

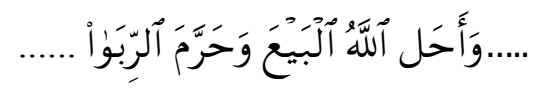

“... Padahal Allah telah menghalalkan jual beli dan mengharamkan riba..."(Q.S Al Baqarah: 275).15

Inflasi adalah kenaikan harga barang-barang yang bersifat umum dan terus menerus. ${ }^{16}$ Dengan kata lain, inflasi juga merupakan proses menurunnya nilai mata uang secara kontinu. Inflasi adalah proses dari suatu peristiwa, bukan tinggirendahnya tingkat harga. Artinya, tingkat harga yang dianggap tinggi belum tentu menunjukan inflasi. Inflasi adalah indikator untuk melihat tingkat perubahan, dan dianggap terjadi jika proses kenaikan harga berlangsung secara terus-menerus dan saling pengaruh-mempengaruhi. Inflasi mempengaruhi tingkah laku instrumen investasi, seperti saham dan obligasi, baik secara langsung maupun tidak langsung. Secara langsung, karena inflasi mengakibatkan turunnya daya beli uang. Secara tidak langsung yaitu melalui perubahan tingkat bunga.

Inflasi dapat disebabkan oleh dua hal, yaitu inflasi tarikan permintaan, karena terjadinya kelebihan likuiditas dan yang kedua adalah inflasi desakan biaya atau penawaran. ${ }^{17}$ Istilah Inflasi tidak pernah tersurat secara eksplisit disebut dalam AlQur'an maupun Hadis. Inflasi yang merupakan permasalahan masyarakat modern, timbul karena beberapa sebab, antara lain keinginan masyarakat untuk mengkonsumsi secara berlebih. Dari sisi inilah, jauh sebelum timbulnya masalah inflasi dalil-dalil dalam Al-Quran maupun Hadis telah memberikan petunjuk dan 
menjelaskan bahwa pada dasarnya manusia sangat mencintai materi, antara lain ditunjukkan dalam QS Ali 'Imran ayat 14 berikut:

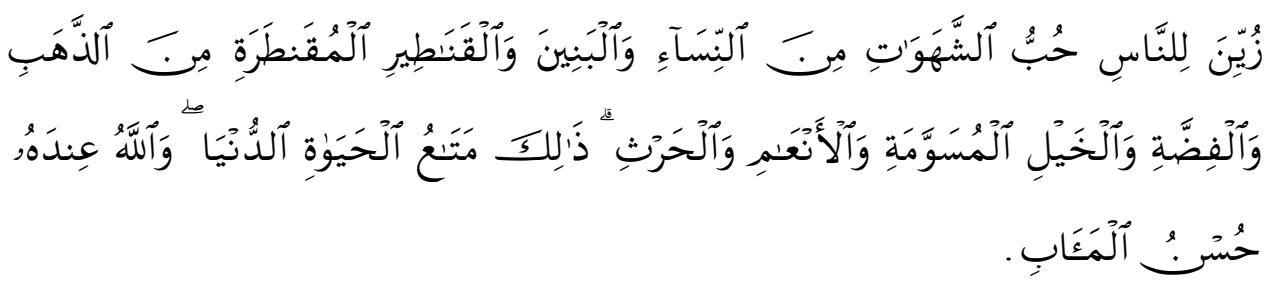

"Dijadikan indah pada (pandangan) manusia kecintaan kepada apa-apa yang diingini, Yaitu: wanita-wanita, anak-anak, harta yang banyak dari jenis emas, perak, kuda pilihan, binatang-binatang ternak dan sawah ladang. Itulah kesenangan hidup di dunia, dan di sisi Allah-lah tempat kembali yang baik (surga)."(Q.S Al Imran :14). ${ }^{18}$

Suku bunga merupakan salah satu variabel dalam perekonomian yang senantiasa diamati secara cermat karena dampaknya yang luas. Ia mempengaruhi secara langsung kehidupan masyarakat keseharian dan mempunyai dampak penting terhadap kesehatan ekonomi. Bunga adalah sejumlah dana dinilai dalam uang, yang diterima si pemberi pinjaman (kreditor), sedangkan suku bunga adalah rasio dari bunga terhadap sejumlah pinjaman. ${ }^{19}$

Tingkat suku bunga Bank Indonesia atau BI Rate adalah suku bunga kebijakan yang mencerminkan sikap atau stance kebijakan moneter yang ditetapkan oleh Bank Indonesia dan diumumkan kepada publik. Bank Indonesia pada umumnya akan menaikkan BI Rate apabila inflasi diperkirakan melampaui sasaran yang telah ditetapkan, sebaliknya Bank Indonesia akan menurunkan BI Rate apabila inflasi berada dibawah perkiraan yang telah ditetapkan. Meningkatnya BI Rate akan menurunkan nilai sekarang dan pendapatan dividen, kondisi seperti ini akan mempengaruhi turunnya harga saham. Hal ini disebabkan karena investor cenderung menanamkan dananya dalam bentuk investasi lainnya, seperti menyimpan dananya pada sektor perbankan. Dapat juga dianalogikan, semakin tinggi tingkat suku bunga Bank Indonesia, semakin tinggi pula tingkat suku bunga deposito dan pinjaman dari bank-bank di dalam negeri. Sehingga investor beralih menanamkan modalnya pada sekuritas perbankan yang memiliki nilai kepastian daripada menanamkan modalnya di pasar modal dimana keuntungan yang diperoleh tidak pasti yang disebabkan harga saham yang berfluktuasi. 
Siti Sunayah, Zaini Ibrahim: Analisis Pengaruh Perubahan...

\section{Kajian Pustaka}

\section{Investasi Dalam Pandangan Islam}

Investasi adalah salah satu cara yang digunakan untuk mengembangkan harta kekayaan yang dimiliki secara produktif. ${ }^{20}$ Saat ini banyak sekali pilihan yang dapat digunakan untuk berinvestasi baik secara real asset maupun financial asset. Asset riil bisa diperoleh dengan cara membeli tanah, emas, dan aset berwujud lainnya. Pilihan lain yang tersedia yaitu financial asset baik melalui pasar modal maupun pasar uang. Di sektor ini, varian produk yang ada sangat banyak karena financial market menyediakan produk mulai dari underlying sampai derivatif.

Investasi merupakan salah satu ajaran dan konsep Islam yang memenuhi proses tadrij dan trichotomy pengetahuan tersebut. Hal tersebut dapat dibuktikan bahwa konsep investasi selain sebagai pengetahuan juga bernuansa spiritual karena menggunakan norma Islam, sekaligus merupakan hakekat dari sebuah ilmu dan amal, oleh karenanya investasi sangat dianjurkan bagi setiap muslim. Sejalan dengan kewajiban bekerja dalam Islam yang telah tertulis dalam Al-Quran dan Hadits maka hukum investasi-pun menjadi halal dan syah, selama dalam teknisnya tidak terkandung hal-hal yang menyalahi prinsip dasar dari transaksi yang halal. Penghalalan tersebut dapat kita lihat dari beberapa dalil yang ada di dalam al-Qur'an dan hadits Rasulullah diantaranya adalah:

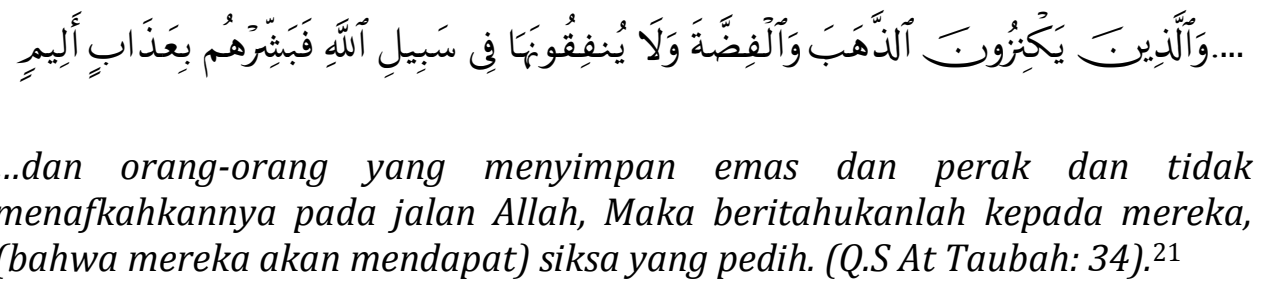

Islam sebagai aturan hidup (nidham al hayat) yang mengatur seluruh sisi kehidupan umat manusia, menawarkan berbagai cara dan kiat untuk menjalani kehidupan yang sesuai dengan norma dan aturan Allah SWT. Dalam berinvestasipun Allah SWT dan Rosul-Nya memberikan petunjuk (dalil) dan rambu-rambu pokok yang seyogianya diikuti oleh stiap muslim yang beriman. Diantara rambu-rambu tersebut adalah sebagai berikut, terbebas dari unsur riba, gharar, judi (maysir), haram, dan syubhat. ${ }^{22}$ 
Islamiconomic: Jurnal Ekonomi Keuangan dan Bisnis Islam Vol.7 No.1 Januari - Juni 2016

Investasi adalah salah satu bentuk implementasi memanfaatkan harta untuk kegiatan produktif. Semakin produktif penggunaan harta tersebut tidak hanya akan menghasilkan pembayaran zakat yang semakin banyak namun juga membuat perekonomian menjadi lebih baik. ${ }^{23}$ Inilah mengapa Islam sangat menganjurkan umatnya untuk berinvestasi karena harta yang diam atau tidak dimanfaatkan tidak akan membawa manfaat positif baik bagi pemegangnya maupun bagi umat. Investasi sebagai salah satu aktivitas ekonomi akan memiliki nuansa spiritual manakala menyertakan norma syariah dalam pelaksanaannya. Berinvestasi secara syariah, maka Insya Allah keuntungan yang bisa diperoleh tidak hanya berupa keuntungan duniawi tetapi juga ukhrawi.

\section{Konsep Pasar Modal}

Pengertian pasar modal menurut Kasmir merupakan tempat para penjual dan pembeli untuk melakukan transaksi. ${ }^{24}$ Undang-Undang Pasar Modal No. 8 tahun 1995 tentang Pasar Modal mendefinisikan pasar modal sebagai kegiatan yang bersangkutan dengan penawaran umum dan perdagangan efek, perusahaan publik yang berkaitan dengan efek yang diterbitkannya, serta lembaga dan profesi yang berkaitan dengan efek. Dapat disimpulkan bahwa Pasar modal (capital market) merupakan pasar untuk berbagai instrumen keuangan jangka panjang yang bisa diperjualbelikan, baik surat utang (obligasi), ekuiti (saham), reksa dana, instrumen derivatif maupun instrumen lainnya. Pasar modal merupakan sarana pendanaan bagi perusahaan maupun institusi lain (misalnya pemerintah), dan sebagai sarana bagi kegiatan berinvestasi.

\section{Konsep Return}

Return dalam bahasa serhari-hari disebut dengan tingkat keuntungan atau kembalian modal (ma'ad). Return merupakan hasil dari investasi. Return atau pengembalian adalah keuntungan yang diperoleh perusahaan, individu dan institusi dari hasil kebijakan investasi yang dilakukan. 
Siti Sunayah, Zaini Ibrahim: Analisis Pengaruh Perubahan...

\section{Hubungan Nilai Tukar Rupiah (kurs) Dengan Return Saham}

Kurs merupakan variabel makroekonomi yang turut mempengaruhi volatilitas harga saham. Depresiasi mata uang domestik akan meningkatkan volume ekspor. Bila permintaan pasar internasional cukup elastis hal ini akan meningkatkan cash flow perusahaan domestik, yang kemudian meningkatkan harga saham, yang tercermin pada IHSG. Sebaliknya, jika emiten membeli produk dalam negeri, dan memiliki hutang dalam bentuk dollar maka harga sahamnya akan turun. Depresiasi kurs akan menaikkan harga saham yang tercermin pada IHSG dalam perekonomian yang mengalami inflasi. ${ }^{25}$ Nilai tukar berubah karena adanya faktor yang mempengaruhi yaitu tingkat inflasi, tingkat suku bunga riil, pertumbuhan ekonomi, aliran modal, independensi bank sentral, dan risiko ekonomi dan politik. Risiko nilai tukar sangat berkaitan dengan fluktuasi nilai tukar mata uang domestik dengan nilai mata uang negara lain. Bagi perusahaan yang berorientasi ekspor, depresiasi terhadap nilai mata uang memberikan pengaruh yang menguntungkan bagi perusahaan. Hal ini dikarenakan kemampuan bersaing harga pokoknya di pasar internasional meningkat. Peningkatan ini selanjutnya akan memperbesar peluang perusahaan untuk menghasilkan laba dan meningkatkan kemampuan dalam memberikan dividen. Kemampuan menghasilkan laba dan membagikan dividen akan menarik minat investor sehingga harga saham naik. Kenaikan harga saham akan meningkatkan return yang diperoleh oleh investor.

\section{Hubungan Suku Bunga Dengan Return Saham}

Harga sebuah saham dipengaruhi tingkat suku bunga. Pengaruh tersebut bersifat negatif, jika tingkat suku bunga naik maka harga saham mengalami penurunan. Tingkat suku bunga yang meningkat akan berdampak pada suku bunga pinjaman yang naik. Suku bunga simpanan naik mengakibatkan meningkatnya pula tingkat suku bunga kredit oleh bank, sehingga biaya bunga yang ditanggung oleh para debitor yang sebagian besar pada sektor usaha menjadi semakin besar, hal ini mengakibatkan penurunan tingkat laba bahkan perusahaan bisa merugi. Perusahaan yang mengalami risiko suku bunga, harga sahamnya akan turun karena investor melihat perusahaan tersebut memiliki prospek yang tidak bagus. Tingkat bunga merupakan harga yang terjadi di pasar investasi. Dalam lembaga keuangan, tingkat 
Islamiconomic: Jurnal Ekonomi Keuangan dan Bisnis Islam Vol.7 No.1 Januari - Juni 2016

bunga berfungsi sebagai return atas tabungan yang dilakukan. Tingkat bunga merupakan harapan atas ekspektasi masyarakat di masa mendatang.

\section{Hubungan Inflasi Dengan Return Saham}

Tingkat inflasi yang tinggi biasanya dikaitkan dengan kondisi ekonomi yang terlalu panas (overheated). Artinya, kondisi ekonomi mengalami permintaan atas produk yang melebihi kapasitas penawaran produknya, sehingga harga-harga cenderung mengalami kenaikan. Inflasi yang terlalu tinggi juga akan menyebabkan penurunan daya beli uang (purchasing power of money). Di samping itu, inflasi yang tinggi juga bisa mengurangi tingkat pendapatan riil yang diperoleh investor dari investasinya. Sebaliknya jika tingkat inflasi suatu negara mengalami penurunan, maka hal ini merupakan sinyal yang positif bagi investor seiring dengan turunnya risiko daya beli uang dan risiko penurunan pendapatan riil. Jadi inflasi yang tinggi menyebabkan menurunnya keuntungan suatu perusahan, sehingga menyebabkan efek ekuitas menjadi kurang kompetitif.

\section{Penelitian Terdahulu}

Dalam beberapa penelitian terdahulu hubungan antara kondisi makroekonomi dalam aktivitas dan kinerja pasar modal, diantaranya telah dibuktikan oleh Heliyani, yang meneliti tentang pengaruh tingkat suku bunga (SBI) dan inflasi terhadap return saham perusahaan farmasi, dengan periode penelitian dari tahun 2001 sampai dengan tahun 2005.Ia menggunakan metode regresi linier berganda, diperoleh hasil penelitian yang menunjukan bahwa inflasi dan tingkat suku bunga (SBI) berpengaruh positif terhadap return saham pada industri farmasi. Artinya kenaikan inflasi dan tingkat suku Bunga (SBI) akan mengakibatkan kenaikan return saham pada industri farmasi. 26

Penelitian yang dilakukan oleh Rini Dwi Astuti yang membuktikan bahwa variabel makro ekonomi (kurs, suku bunga deposito, suku bunga luar negeri), serta variabel dummy yang berupa krisis moneter 1997 mempunyai pengaruh terhadap kinerja Bursa Efek Jakarta yang diukur melalui Indeks Harga Saham Gabungan (IHSG). ${ }^{27}$ 
Siti Sunayah, Zaini Ibrahim: Analisis Pengaruh Perubahan...

Penelitian lain seperti yang dilakukan oleh Imronudin tentang pengaruh kebijakan moneter terhadap hubungan model tiga faktor (beta, size, book to market equity) dengan return saham, memperlihatkan bahwa model tiga faktor baik beta, size, maupun book to market equity baik secara bersama-sama maupun individual tidak berpengaruh terhadap return saham. ${ }^{28}$

Hasil tersebut berbeda dengan penelitian Robiatul Auliyah dan Ardi Hamzah menunjukan karakteristik perusahaan, industri dan ekonomi makro berpengaruh terhadap return dan beta saham syariah di BEJ. ${ }^{29}$

\section{Hipotesis}

Sesuai dengan masalah yang diangkat, hipotesis atau dugaan sementara yang diajukan dalam penelitian ini dibagi ke dalam dua kelompok, yaitu untuk keperluan uji simultan/bersama-sama (uji F), dan untuk keperluan uji parsial/masing-masing (uji t).

\section{Hipotesis untuk uji simultan (uji F)}

Ho: $\beta \mathrm{i}=0$, diduga ketiga variabel bebas tidak berpengaruh secara simultan terhadap variabel terikat.

Ha: $\beta \mathrm{i} \neq 0$, diduga ketiga variabel bebas tidak berpengaruh secara simultan terhadap variabel terikat.

\section{Hipotesis untuk uji parsial (uji t)}

1). Nilai Tukar Rupiah

Ho: $\beta_{1}=0$, diduga nilai tukar rupiah tidak berpengaruh positif terhadap return saham syariah PT. Telekomunikasi Indonesia, Tbk.

Ha: $\beta_{1}>0$, diduga nilai tukar rupiah berpengaruh positif terhadap return saham syariah PT. Telekomunikasi Indonesia, Tbk.

2). Suku Bunga

Ho: $\beta_{2}=0$, diduga suku bunga tidak berpengaruh negatif terhadap return saham syariah PT. Telekomunikasi Indonesia, Tbk.

Ha: $\beta_{2}<0$, diduga suku bunga berpengaruh negatif terhadap return saham syariah PT. Telekomunikasi Indonesia, Tbk. 
3). Tingkat Inflasi

Ho: $\beta_{3}=0$, diduga tingkat inflasi tidak berpengaruh negatif terhadap return saham syariah PT. Telekomunikasi Indonesia, Tbk.

Ha: $\beta_{3}<0$, diduga tingkat inflasi berpengaruh negatif terhadap return saham syariah PT.Telekomunikasi Indonesia, Tbk.

\section{Metodologi Penelitian}

\section{Objek Penelitian}

Penelitian dilakukan terhadap return saham syariah dari PT. Telekomunikasi Idonesia, Tbk. Pemanfaatan PT. Telkom karena saham perusahaan ini muncul berturut-turut selama 3 tahun (2011 sampai 2013) dalam daftar JII.

\section{Teknik Pengumpulan Data}

Data yang digunakan dalam penelitian ini seluruhnya menggunakan data sekunder yang terdiri dari:

1. Data return saham diperoleh dari perhitungan rumus return yaitu selisih harga jual saham dengan harga beli saham ditambahkan dengan dividen saham pada PT. Telekomunikasi Indonesia, Tbk. Data umum harga jual saham, harga beli saham dan dividen berasal dari Indonesia Stock Exchange (IDX) Monthly Statistic selama periode 2011 sampai 2013.

2. Data nilai tukar, suku bunga dan inflasi yang digunakan dalam penelitian ini diperoleh yang diperoleh dari Statistik Ekonomi dan Keuangan yang diterbitkan Bank Indonesia.

\section{Teknik Analisis Data}

\section{Analisis Regresi Linier Berganda}

Untuk menjawab pertanyaan penelitian ini, penulis merumuskan sebuah model ekonometrik yang akan dilakukan serangkaian pengujian terhadapnya, sehingga model ini layak digunakan sebagai alat peramalan. Model ekonometrik ini menggambarkan hubungan antara nilai tukar, suku bunga, dan inflasi dengan return saham syariah PT. Telkom, yaitu: 
Siti Sunayah, Zaini Ibrahim: Analisis Pengaruh Perubahan...

$$
\text { Return }=\alpha+\beta_{1} \text { kurs }-\beta_{2} S B-\beta_{3} \operatorname{Inf}+\dot{\varepsilon} t
$$

Di mana: return = Return saham syariah PT Telkom

$$
\begin{array}{ll}
\alpha & =\text { Konstanta } \\
\beta_{1}, \beta_{2}, \beta_{3} & =\text { Koefisien Regresi } \\
\text { kurs } & =\text { Nilai tukar rupiah (Rp) } \\
\text { SB } & =\text { Suku bunga acuan BI Rate (\%) } \\
\text { Inf } & =\text { Tingkat Inflasi (\%) }
\end{array}
$$

Model di atas dianalisis dengan menggunakan metode OLS (Ordinary Least Square). Dalam metode ini ada beberapa pengujian yang harus dilewati agar menghasilkan model/persamaan regresi yang prediktif. Pengujian yang dimaksud adalah sebagai berikut:

\section{a. Uji autokolerasi}

Menguji autokolerasi dalam suatu model bertujuan untuk mengetahui ada tidaknya korelasi ada tidaknya variabel pengganggu periode sebelumnya ( $\left.\mathrm{e}_{\mathrm{t}-1}\right)$. Autokolerasi adalah kolerasi antara sesama urutan pengamatan dari waktu ke waktu (time series). ${ }^{30}$ Autokolerasi dapat berbentuk autokolerasi positif dan autokolerasi negatif. ${ }^{31}$ Untuk mengetahui adanya masalah autokolerasi pada model regresi dengan menggunakan uji Durbin Watson (DW), yaitu membandingkan nilai DW hasil output eviews dengan tabel DW. Kriteria uji DW mengikuti tabel 1 berikut ini.

\section{Tabel 1. Uji Statistik Durbin Watson}

\begin{tabular}{|l|l|}
\hline \multicolumn{1}{|c|}{ Nilai Statistik } & \multicolumn{1}{|c|}{ Hasil } \\
\hline $0<\mathrm{d}<\mathrm{dl}$ & Menolak hipotesis nol, ada autokolerasi positif. \\
$\mathrm{dl} \leq \mathrm{d} \leq \mathrm{du}$ & Daerah keragu-raguan, tidak ada keputusan. \\
$\mathrm{du}<\mathrm{d}<4-\mathrm{du}$ & Menerima hipotesis nol, tidak ada autokolerasi \\
$4-\mathrm{du}<\mathrm{d}<4-\mathrm{dl}$ & positif/negatif. \\
$4-\mathrm{dl} \leq \mathrm{d} \leq 4$ & Daerah keragu-raguan, tidak ada keputusan. \\
& Menolak hipotesis nol, ada autokolerasi negatif. \\
\hline
\end{tabular}

b. Uji heteroskedastisitas 
Islamiconomic: Jurnal Ekonomi Keuangan dan Bisnis Islam Vol.7 No.1 Januari - Juni 2016

Asumsi ini apabila variasi dari faktor pengganggu selalu sama pada data pengamatan yang satu ke data pengamatan yang lain. Jika ciri ini terpenuhi, berarti variasi faktor pengganggu pada data tersebut bersifat homoskedastik. Jika asumsi itu tidak dapat dipenuhi maka dapat dikatakan terdapat penyimpangan. Penyimpangan terhadap faktor pengganggu sedemikian itu disebut heteroskedastisitas. Model regresi yang baik adalah yang homoskedastik atau tidak terjadi heteroskedastisitas.

Cara untuk mengetahui ada atau tidaknya heteroskedastisitas pada suatu model dapat dilihat dari pola gambar scatterplot model tersebut. Analisis pada gambar scatterplot yang menyatakan model regresi linier berganda tidak terdapat heteroskedastisitas jika :

1) Titik-titik data menyebar di atas dan di bawah atau sekitar angka 0.

2) Titik-titik data tidak mengumpul hanya di atas atau di bawah saja.

3) Penyebaran titik-titik data tidak boleh membentuk pola bergelombang melebar kemudian menyempit dan melebar kembali.

4) Penyebaran titik-titik data sebaiknya tidak berpola.

c. Uji multikolinearitas

Uji multikolinearitas digunakan untuk mendeteksi ada tidaknya hubungan antar beberapa atau semua variabel independen dalam model regresi. Multikolinearitas adalah kondisi adanya hubungan linear antar variabel independen. ${ }^{32}$ Multikolinearitas merupakan keadaan dimana satu atau lebih variabel independen dinyatakan sebagai kondisi linear dengan variabel lainnya. Artinya jika diantara variabel bebas yang digunakan sama sekali tidak berkolerasi satu dengan yang lain maka bisa dikatakan tidak terjadi multikolinearitas.

Untuk menguji asumsi multikolinearitas dapat digunakan VIF (variance inflation factor). Nilai VIF (variance inflation factor) adalah faktor penyimpangan baku kuadrat, dimana dalam menguji ini bisa dilihat tidak ada kolinieritas jika VIF mendekati angka 1.

\section{Pengujian Hipotesis}

a. Uji F (Uji Secara Simultan) 
Siti Sunayah, Zaini Ibrahim: Analisis Pengaruh Perubahan...

Pengujian ini melibatkan ketiga variabel bebas (nilai tukar, inflasi dan suku bunga) terhadap variabel terikat (return saham) untuk menguji ada tidaknya pengaruh yang signifikan secara bersama-sama maupun secara simultan.

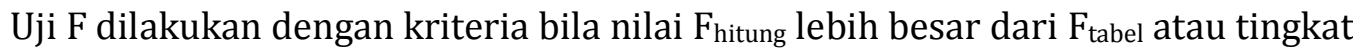
signifikannya lebih kecil dari 5\% $(\alpha: 5 \%=0,05)$ maka hal ini menunjukan bahwa $\mathrm{H}_{0}$ ditolak dan $\mathrm{H}_{\mathrm{a}}$ diterima yang berarti bahwa variabel independen mempunyai pengaruh signifikan terhadap variabel dependen. Adapun hipotesis yang digunakan telah diuraikan pada sub bab hipotesis.

\section{b. Uji t (Uji Secara Parsial)}

Uji t digunakan untuk menganalisis pengaruh variabel independen terhadap variabel dependen secara parsial. Bila t hitung lebih besar dari t tabel atau nilai signifikan $\mathrm{t}<0.05$, maka $\mathrm{H}_{0}$ ditolak dan $\mathrm{H}_{\mathrm{a}}$ diterima, yang berarti bahwa terdapat pengaruh signifikan secara parsial variabel independen terhadap variabel dependen. Hipotesis yang akan diuji telah diuraikan pada sub bab hipotesis.

\section{Koefisien Determinasi ( $\left.\mathbf{R}^{2}\right)$}

Koefisien determinasi digunakan untuk melihat seberapa besar kemampuan variabel independen menjelaskan variabel dependen yang dilihat melalui adjusted $\mathrm{R}$ square karena variabel independennya lebih dari 2. Koefisien determinasi ( $\left.\mathrm{R}^{2}\right)$ pada intinya mengukur seberapa jauh kemampuan model dalam menerangkan variabel terikat. Dengan nilai koefisien determinasi adalah antara nol sampai dengan satu. Ukuran goodness of fit ini mencerminkan seberapa besar variasi dari regressand variabel terikat yang diterangkan oleh regressor variabel bebas. Bila $\mathrm{R}^{2}=0$, artinya variasi dari variabel terikat tidak dapat diterangkan oleh variabel bebas. Sementara bila $\mathrm{R}^{2}=1$, artinya variasi dai variabel terikat $100 \%$ dapat diterangkan oleh variabel bebas. Dengan kata lain, apabila $\mathrm{R}^{2}=1$, maka semua titik pengamatan berada pada garis regresi. Dengan demikian ukuran goodness of fit dari suatu model ditentukan oleh $\mathrm{R}^{2}$ yan nilainya antara nol sampai dengan satu. ${ }^{33}$ 


\section{Pembahasan Hasil Penelitian}

\section{Deskripsi Data}

Semua data yang digunakan dalam penelitian ini adalah data sekunder deret waktu (time series) yang berbentuk bulanan dari tahun 2011-2013. Tabel 2 di bawah ini merupakan rekapitulasi data yang digunakan dalam riset ini.

Tabel 2. Data Nilai Tukar, Suku Bunga, Inflasi dan Return Saham Syariah PT. Telekomunikasi Indonesia, Tbk.

\begin{tabular}{|c|c|c|c|c|c|}
\hline Tahun & Bulan & $\begin{array}{l}\text { Nilai Tukar } \\
\text { (Rp) }\end{array}$ & $\begin{array}{l}\text { Suku } \\
\text { Bunga }\end{array}$ & Inflasi & Return \\
\hline \multirow{12}{*}{$\underset{\text { 궁 }}{\stackrel{\sim}{\circ}}$} & 1 & 9.012 & $6.00 \%$ & $7.02 \%$ & 0.086286623 \\
\hline & 2 & 8.779 & $6.00 \%$ & $6.84 \%$ & 0.047176377 \\
\hline & 3 & 8.665 & $6.50 \%$ & $6.65 \%$ & 0.047818232 \\
\hline & 4 & 8.531 & $6.75 \%$ & $6.16 \%$ & $\begin{array}{c}- \\
0.012796882\end{array}$ \\
\hline & 5 & 8.494 & $6.75 \%$ & $5.98 \%$ & 0.032657663 \\
\hline & 6 & 8.554 & $6.75 \%$ & $5.54 \%$ & 0.081831837 \\
\hline & 7 & 8.465 & $6.75 \%$ & $4.61 \%$ & 0.036309387 \\
\hline & 8 & 8.535 & $6.75 \%$ & $4.79 \%$ & 0.050603309 \\
\hline & 9 & 8.779 & $6.75 \%$ & $4.61 \%$ & 0.010937633 \\
\hline & 10 & 8.791 & $6.75 \%$ & $4.42 \%$ & 0.06309108 \\
\hline & 11 & 9.124 & $6.75 \%$ & $4.15 \%$ & 0.043112108 \\
\hline & 12 & 9.023 & $6.50 \%$ & $3.79 \%$ & 0.080407659 \\
\hline \multirow{12}{*}{$\underset{\sim}{\stackrel{N}{\sim}}$} & 1 & 8.955 & $5.75 \%$ & $3.65 \%$ & 0.068156787 \\
\hline & 2 & 9.040 & $5.75 \%$ & $3.56 \%$ & 0.009485673 \\
\hline & 3 & 9.134 & $5.75 \%$ & $3.97 \%$ & 0.045267713 \\
\hline & 4 & 9.144 & $5.75 \%$ & $4.50 \%$ & $\begin{array}{c}- \\
0.145073648 \\
\end{array}$ \\
\hline & 5 & 9.517 & $5.75 \%$ & $4.45 \%$ & 0.123958204 \\
\hline & 6 & 9.433 & $5.75 \%$ & $4.53 \%$ & -0.01019951 \\
\hline & 7 & 9.438 & $5.75 \%$ & $4.56 \%$ & $\begin{array}{c}- \\
0.063661207 \\
\end{array}$ \\
\hline & 8 & 9.512 & $5.75 \%$ & $4.58 \%$ & 0.018353012 \\
\hline & 9 & 9.540 & $5.75 \%$ & $4.31 \%$ & 0.0233527 \\
\hline & 10 & 9.567 & $5.75 \%$ & $4.61 \%$ & 0.00724954 \\
\hline & 11 & 9.557 & $5.75 \%$ & $4.32 \%$ & 0.124520335 \\
\hline & 12 & 9.622 & $6.00 \%$ & $4.30 \%$ & 0.047003689 \\
\hline \multirow{3}{*}{$\stackrel{m}{\stackrel{m}{\circ}}$} & 1 & 9.650 & $6.50 \%$ & $4.57 \%$ & 0.059168524 \\
\hline & 2 & 9.619 & $6.00 \%$ & $5.31 \%$ & $\begin{array}{c}- \\
0.039719056 \\
\end{array}$ \\
\hline & 3 & 9.670 & $5.75 \%$ & $5.90 \%$ & $\begin{array}{c}- \\
0.032128486 \\
\end{array}$ \\
\hline
\end{tabular}


Siti Sunayah, Zaini Ibrahim: Analisis Pengaruh Perubahan...

\begin{tabular}{|c|c|c|c|c|c|}
\hline Tahun & Bulan & $\begin{array}{c}\text { Nilai Tukar } \\
\text { (Rp) }\end{array}$ & $\begin{array}{c}\text { Suku } \\
\text { Bunga }\end{array}$ & Inflasi & Return \\
\hline \multirow{6}{*}{4} & 9.673 & $5.75 \%$ & $5.57 \%$ & 0.021219521 \\
\cline { 2 - 5 } & 5 & 9.753 & $5.75 \%$ & $5.47 \%$ & - \\
\cline { 2 - 6 } & 6 & 9.879 & $5.75 \%$ & $5.90 \%$ & 0.170356768 \\
\hline \multirow{4}{*}{7} & 10.227 & $5.75 \%$ & $8.61 \%$ & - \\
\cline { 2 - 6 } & 8 & 10.869 & $7.50 \%$ & $8.79 \%$ & 4.337570352 \\
\cline { 2 - 6 } & 9 & 11.555 & $7.50 \%$ & $8.40 \%$ & 0.05045605 \\
\cline { 2 - 6 } & 10 & 11.178 & $7.25 \%$ & $8.32 \%$ & -0.03886224 \\
\cline { 2 - 6 } & 11 & 11.917 & $7.25 \%$ & $8.37 \%$ & 0.070809529 \\
\cline { 2 - 6 } & 12 & 12.128 & $7.00 \%$ & $8.38 \%$ & 0.057267322 \\
\hline
\end{tabular}

Dari data di atas dapat dideskripsikan sebagai berikut, selama tiga tahun terakhir, nilai tukar rupiah terhadap dolar AS rata-rata mencapai Rp 9.537, dengan nilai tertinggi mencapai Rp 12.128 yang terjadi saat Desember 2013. Sedangkan nilai terendah mencapai Rp 8.465 saat bulan Juli 2011.

Untuk suku bunga selama periode 2011 sampai 2013 nilai rata-ratanya mencapai 6,30\%, dengan suku bunga tertinggi mencapai 7,50\% yang terjadi selama bulan Agustus dan september 2013. Sedangkan untuk suku bunga terendah mencapai 5,75\% yang terjadi selama bulan Januari sampai November 2012, dilanjutkan saat bulan Maret sampai Juli 2013.

Untuk variabel inflasi sendiri, selama periode 2011 sampai 2013, rata-rata inflasi mencapai 5,5\%. Nilai inflasi tertinggi di kisaran 8,79\% terjadi pada bulan Agustus 2013, sebaliknya inflasi rendah terjadi pada bulan Februari 2012 sebesar $3,56 \%$.

Terakhir untuk return saham syariah PT. Telkom selama periode 2011 sampai 2013 nilai rata-ratanya mencapai 1,20\%, dengan return tertinggi terjadi pada bulan Agustus 2013 sebesar 4,3\%. Sebaliknya return terendah tercapai di bulan April 2012 mencapai $-0.145 \%$. 


\section{Analisis Data}

\section{Autokolerasi}

\section{Tabel 3. Hasil Uji Durbin Watson}

\begin{tabular}{|c|c|c|c|c|}
\hline \multicolumn{5}{|c|}{$\begin{array}{l}\text { Dependent Variable: RETURN } \\
\text { Method: Least Squares } \\
\text { Date: 10/19/14 Time: 16:43 } \\
\text { Sample: 2011M01 2013M12 } \\
\text { Included observations: } 36\end{array}$} \\
\hline & Coefficien & & & \\
\hline Variable & $\mathrm{t}$ & Std. Error & t-Statistic & Prob. \\
\hline $\mathrm{C}$ & -2.467387 & 1.790826 & -1.377793 & 0.1778 \\
\hline NILAI_TUKAR & $1.76 \mathrm{E}-05$ & 0.000167 & 0.104916 & 0.9171 \\
\hline SUKU_BUNGA & 31.40280 & 23.57839 & 1.331846 & 0.1923 \\
\hline INFLASI & 0.086049 & 0.110351 & 0.779774 & 0.4413 \\
\hline R-squared & 0.164548 & \multirow{2}{*}{\multicolumn{3}{|c|}{ Mean dependent var 0.148225}} \\
\hline Adjusted R- & & & & \\
\hline squared & 0.086224 & \multicolumn{3}{|c|}{ S.D. dependent var $\quad 0.720758$} \\
\hline S.E. of regression & 0.688984 & \multicolumn{3}{|c|}{ Akaike info criterion 2.197241} \\
\hline Sum squared resid & 15.19036 & \multicolumn{2}{|c|}{ Schwarz criterion } & 2.373188 \\
\hline Log likelihood & -35.55034 & \multicolumn{3}{|c|}{$\begin{array}{r}\text { Hannan-Quinn criter. } 2.258651 \\
2.21691\end{array}$} \\
\hline F-statistic & 0.022872 & \multirow{2}{*}{\multicolumn{2}{|c|}{ Durbin-Watson stat }} & 4 \\
\hline Prob(F-statistic) & 0.019637 & & & \\
\hline
\end{tabular}

Dari hasil perhitungan dengan menggunakan eviews7 didapat nilai statistik Durbin Watson sebesar 2,21694 dan terletak diantara batas atau upper bound ( $\mathrm{du}=$ 1,54) dan $(4-d u=2,46)$. Dengan demikian dapat disimpulkan model regresi tidak terjadi autokolerasi.

\section{Heteroskedastisitas}

Tabel 4. Hasil Uji White

Heteroskedasticity Test: White

\begin{tabular}{lclr}
\hline \hline F-statistic & 6.618502 & $\begin{array}{l}\text { Prob. F(9,26) } \\
\text { Prob. Chi- }\end{array}$ & 0.0001 \\
Obs*R-squared & \multicolumn{2}{c}{ 25.06114Square(9) } & $\mathbf{0 . 0 0 2 9}$ \\
Scaled explained SS & 224.2397 & Prob. Chi-Square(9) & 0.0000 \\
\hline \hline
\end{tabular}

Test Equation:

Dependent Variable: RESID^2 
Siti Sunayah, Zaini Ibrahim: Analisis Pengaruh Perubahan...

Method: Least Squares

Date: 10/19/14 Time: 18:26

Sample: 2011M01 2013M12

Included observations: 36

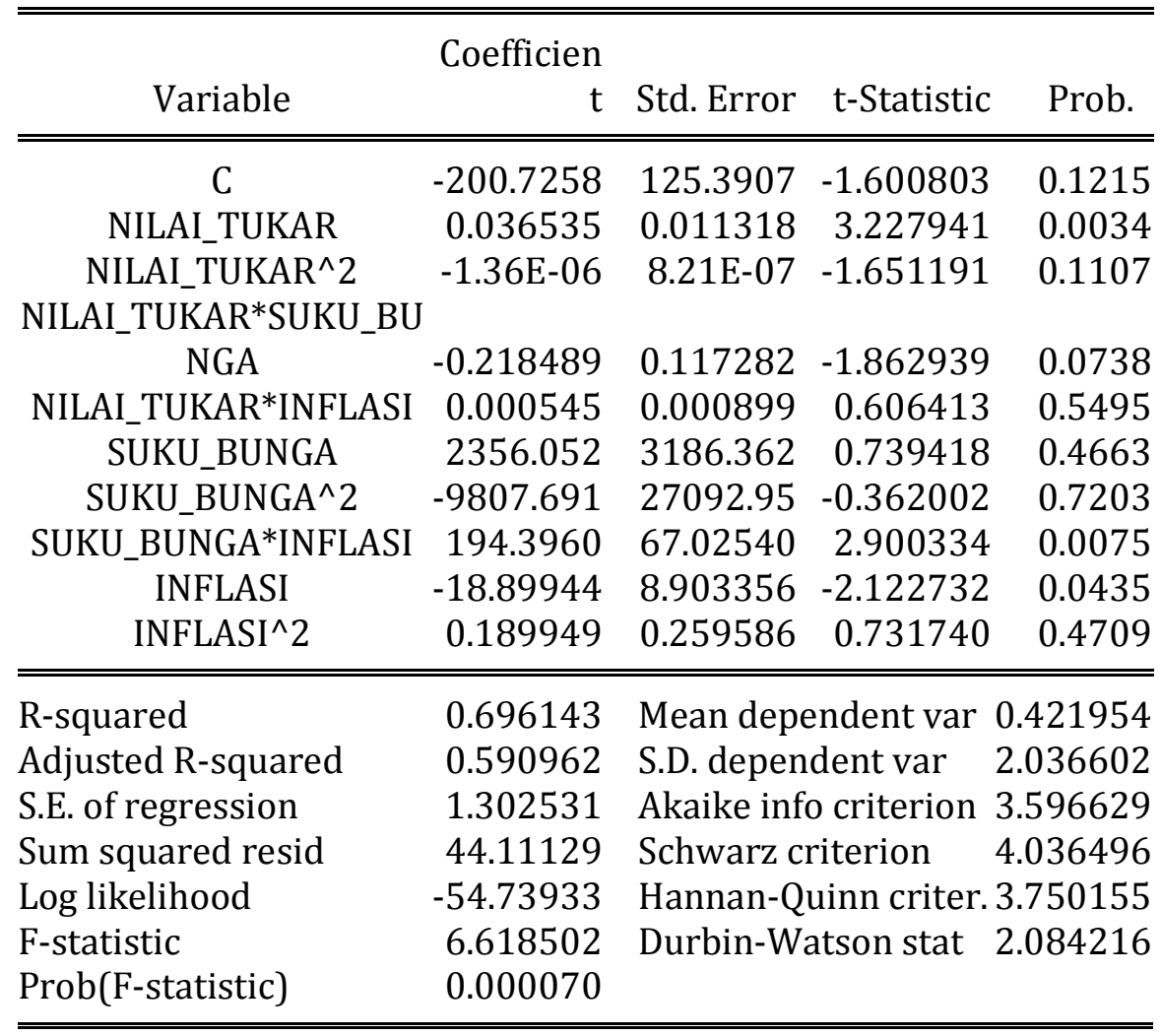

Uji white menggunakan residual kuadrat sebagai variabel dependen, dan variabel independennya terdiri atas variabel independen yang sudah ada, ditambah dengan kuadrat variabel independen. Dari hasil pengujian tersebut didapat Nilai Obs*R-squared adalah 25.06114 dan nilai probabilitasnya adalah 0.0029 (lebih kecil dari $\alpha=5 \%$ maka dapat disimpulkan bahwa data tersebut bersifat heteroskedastisitas. Residual yang mengandung heteroskedastisitas akan berakibat:

1) Estimator kuadrat terkecil tidak mempunyai varian yang minimum (tidak lagi best), sehingga hanya memenuhi karakteristik LUE (linier unbiased estimator)

2) Perhitungan standard error tidak dapat dipercaya karena varian tidak minimum, dan varian tidak minimum mengakibatkan estimasi regresi tidak efisien.

3) Uji hipotesis yangdidasarkan pada uji t dan uji F tidak dapat dipercaya karena standard error-nya tidak dapat dipercaya. 
Islamiconomic: Jurnal Ekonomi Keuangan dan Bisnis Islam Vol.7 No.1 Januari - Juni 2016

Untuk menghilangkan heterskedastisitas, penulis menggunakan metode white seperti yang tercantum dalam tabel 5 berikut.

Tabel 5. Hasil Uji Pengobatan Metode White

Dependent Variable: RETURN

Method: Least Squares

Date: 10/19/14 Time: 18:30

Sample: 2011M01 2013M12

Included observations: 36

White heteroskedasticity-consistent standard errors \& covariance

\begin{tabular}{|c|c|c|c|c|}
\hline \multicolumn{5}{|c|}{ Coefficien } \\
\hline Variable & $\mathrm{t}$ & Std. Error & t-Statistic & Prob. \\
\hline $\mathrm{C}$ & -2.467387 & 2.412803 & -1.022623 & 0.3142 \\
\hline NILAI_TUKAR & $1.76 \mathrm{E}-05$ & 0.000104 & 0.169028 & 0.8668 \\
\hline SUKU_BUNGA & 31.40280 & 26.94514 & 1.165435 & 0.2525 \\
\hline INFLASI & 0.086049 & 0.091456 & 0.940871 & 0.3538 \\
\hline -squared & 0.164548 & \multicolumn{3}{|c|}{ Mean dependent var 0.148225} \\
\hline Adjusted R- & & \multicolumn{3}{|c|}{ depende } \\
\hline $\begin{array}{l}\text { squared } \\
\text { S.E. of regression }\end{array}$ & $\begin{array}{l}0.086224 \\
0.688984\end{array}$ & \multicolumn{2}{|c|}{ Akaike info criterion } & $\begin{array}{l}0.120 / 58 \\
2.197241\end{array}$ \\
\hline Sum squared resid & 15.19036 & \multicolumn{2}{|c|}{ Schwarz criterion } & 2.373188 \\
\hline Log likelihood & -35.55034 & \multirow{2}{*}{\multicolumn{2}{|c|}{$\begin{array}{l}\text { Hannan-Quinn criter } \\
\text { Durbin-Watson stat }\end{array}$}} & 2.258651 \\
\hline F-statistic & 0.022872 & & & 2.216914 \\
\hline Prob(F-statistic) & 0.019637 & & & \\
\hline
\end{tabular}

\section{Multikolinearitas}

Pengujian selanjutnya adalah uji multikolinearitas, yaitu untuk mengetahui apakah antar variabel bebas memiliki korelasi atau tidak. Perhatikan tabel 6 berikut ini.

\section{Tabel 6. Hasil Uji Multikolinearitas}

Variance Inflation Factors

Date: 10/19/14 Time: 19:05

Sample: 2011M01 2013M12

Included observations: 36

\begin{tabular}{cccc}
\hline \hline & \multicolumn{3}{c}{ Coefficient } \\
Variable & Variance & VIF & VIF \\
\hline \hline
\end{tabular}


Siti Sunayah, Zaini Ibrahim: Analisis Pengaruh Perubahan...

$\begin{array}{cccc}\text { C } & 5.821616 & 5789.302 & \text { NA } \\ \text { NILAI_TUKAR } & 1.08 E-08 & 924.1262 & \mathbf{1 . 5 0 6 4 9 0} \\ \text { SUKU_BUNGA } & 726.0407 & 2672.803 & \mathbf{3 . 8 0 1 5 9 6} \\ \text { INFLASI } & 0.008364 & 204.5393 & \mathbf{3 . 4 9 4 5 6 5}\end{array}$

Untuk mendeteksi multikolinieritas penulis menggunakan formula Variance Inflation Factor (VIF), pada tabel hasil dari output eviews terlihat masing-masing nilai VIF, yaitu nilai tukar rupiah $=1.506490$, suku bunga $=3.801596$, dan inflasi $=$ 3.494565. Dari hasil tersebut hanya 2 variabel yang mendekati 1, yaitu variabel kurs, sedangkan dua variabel bebas lainnya mengandung kolinieritas.

\section{Uji Hipotesis}

a. Uji F

Merujuk kembali ke tabel 5, terlihat bahwa variabel independen (nilai tukar, suku bunga dan inflasi) mempunyai signifikan $\mathrm{F}$ hitung sebesar 0.022872 dengan probabilitas 0.019637, memiliki tingkat signifikansi yang lebih kecil dari 5\% atau $(0,05)$. Sehingga dapat dikatakan bahwa secara bersama-sama variabel independen (nilai tukar/ kurs, suku bunga, dan inflasi) berpengaruh terhadap return. Dengan demikian $\mathrm{H}_{0}$ ditolak dan $\mathrm{H}_{\mathrm{a}}$ diterima.

\section{b. Uji t}

Berdasarkan tabel 5 juga, dapat diambil keputusan sebagai berikut:

1) Pengujian terhadap variabel bebas nilai tukar. Berdasarkan hasil perhitungan data menggunakan program Eview 7. Diperoleh hasil $t=0.169028$ dengan probabilitas 0.8668 . Ini berarti keputusan terima Ho dan tolak $\mathrm{Ha}$, artinya perubahan yang terjadi pada nilai tukar tidak berpengaruh terhadap naik turunnya return saham syariah PT. Telkom.

2) Pengujian terhadap variabel suku bunga. Berdasarkan hasil perhitungan, diperoleh $\mathrm{t}$ hitung sebesar 1.165435 dengan probabilitas 0.2525 . Ini berarti keputusan terima Ho dan tolak $\mathrm{Ha}$, artinya perubahan suku bunga tidak berpengaruh terhadap perubahan return.

3) Pengujian terhadap variabel Inflasi. Berdasarkan hasil perhitungan diperoleh hasil $t=0.940871$ dengan probabilitas 0.3538 . Ini berarti keputusan terima Ho 
Islamiconomic: Jurnal Ekonomi Keuangan dan Bisnis Islam Vol.7 No.1 Januari - Juni 2016

dan tolak $\mathrm{Ha}$, artinya perubahan inflasi tidak berpengaruh signifikan terhadap return.

\section{Koefisisen Determinasi $\left(R^{2}\right)$}

Berdasarkan tabel 5 diperoleh nilai adjusted $\mathrm{R}^{2} 0.086224$ atau 8,6\%. Hal ini menunjukkan bahwa 8,6 \% kinerja return dipengaruhi oleh variabel nilai tukar, tingkat bunga dan inflasi. Sisanya sebesar 91,4 \% dijelaskan oleh variabel lain.

\section{Analisis Regresi Linier Berganda}

Dari hasil output Eviews dalam tabel 5, model regresi yang dihasilkan adalah:

$$
\text { Return }=-2,46+1,76 \mathrm{KURS}+31,40 \mathrm{SB}+0,08 \mathrm{INF}
$$

Dari model di atas, analisis yang dapat dilakukan adalah sebagai berikut:

a) Nilai konstanta $-2,46$ menunjukkan bahwa ketika tidak terjadi perubahan pada variabel makroekonomi yaitu kurs, suku bunga, dan tingkat inflasi, maka return saham syariah dari PT. Telkom akan mengalami penurunan sebesar $2,46 \%$.

b) Nilai koefisien regresi nilai kurs sebesar 1,76 menunjukkan bahwa apabila terjadi peningkatan nilai tukar rupiah sebesar 1\% akan menaikan besarnya return sebanyak $1,76 \%$, ceteris paribus.

c) Nilai koefisien regresi tingkat bunga sebesar 31,40 artinya apabila terjadi peningkatan tingkat bunga sebesar $1 \%$ akan menaikan besarnya return sebanyak 31,4\%, ceteris paribus.

d) Nilai koefisien regresi tingkat inflasi sebesar 0,08 menunjukkan bahwa setiap peningkatan inflasi sebesar 1\% akan menaikan return sebanyak $0,08 \%$, ceteris paribus.

\section{Penutup}

\section{A. Kesimpulan}

Berdasarkan hasil analisis yang menggunakan regresi berganda dapat disimpulkan bahwa: 
Siti Sunayah, Zaini Ibrahim: Analisis Pengaruh Perubahan...

1. Dari hasil uji parsial/uji t disimpulkan bahwa ketiga variabel makroekonomi yang diangkat dalam penelitian ini, tidak satupun yang secara parsial berpengaruh terhadap return saham syariah PT. Telekomunikasi Indonesia, Tbk. Namun lewat uji simultan/uji F dihasilkan kesimpulan bahwa secara bersama-sama ketiga variabel nilai tukar, suku bunga, dan inflasi berpengaruh terhadap return saham syariah PT. Telekomunikasi Indonesia, Tbk.

2. Untuk melihat besarnya pengaruh ketiga variabel bebas terhadap variabel terikat bisa menggunakan variabel adjusted $\mathrm{R}^{2}$ yang sebesar 0.086. Artinya, variansi dari return saham syariah PT. Telekomunikasi Indonesia, Tbk dijelaskan oleh ketiga variabel bebas nilai tukar, suku bunga, dan inflasi sebesar 8,6\%, sisanya sebesar 91,4\% dijelaskan oleh variabel lain yang tidak dimasukkan ke dalam penelitian.

3. Nilai koefisien variabel kurs sebesar 1,76 menunjukkan ketika terjadi perubahan nilai tukar sebesar 1\% akan berdampak pada peningkatan return saham syariah PT. Telekomunikasi Indonesia, Tbk sebesar 1,76\%, ceteris paribus. Sedangkan nilai koefisien suku bunga sebesar 31,40 menunjukkan ketika terjadi peningkatan suku bunga sebesar 1\% akan berdampak pada peningkatan return saham syariah PT. Telekomunikasi Indonesia, Tbk sebesar 31,40\%, ceteris paribus. Terakhir, nilai koefisien inflasi sebesar 0,086 menunjukkan ketika terjadi kenaikan inflasi sebesar 1\% akan berdampak pada peningkatan return saham syariah PT. Telekomunikasi Indonesia, Tbk sebesar 0,086\%, ceteris paribus.

\section{B. Rekomendasi}

1. Penelitian ini hanya mengambil variabel nilai tukar rupiah/ kurs, suku bunga dan inflasi dari beberapa variabel makroekonomi lainnya yang dianggap memiliki pengaruh terhadap return saham. Ke depan agar bisa ditambahkan faktor-faktor lain seperti gross domestic product (GDP), tingkat pengangguran, transaksi berjalan, dan defisit anggaran maupun faktor-faktor yang berasal dari kinerja perusahaan seperti proyeksi laba per saham, penggunaan hutang, dan kebijakan dividen.

2. Penelitian ini hanya membatasi pada perusahaan-perusahaan yang konsisten yang terdaftar di setiap periode penentuan perusahaan yang dianggap memenuhi syarat untuk bisa terdafatar di Indeks Syariah Jakarta Islamic Index sepanjang tahun 
Islamiconomic: Jurnal Ekonomi Keuangan dan Bisnis Islam Vol.7 No.1 Januari - Juni 2016

2011 sampai dengan tahun 2013. Untuk penelitian selanjutnya diharapkan tidak hanya perusahaan-perusahaan yang konsisten di setiap periode saja yang menjadi sampel penelitian, akan tetapi juga perusahaan-perusahaan yang kurang konsisten terdaftar dalam Jakarta Islamic Index karena bisa jadi diantara perusahaanperusahaan yang tidak dimasukkan dalam sampel merupakan perusahaan yang sahamnya menjadi penggerak indeks.

3. Dari aspek statistika, penelitian ini memiliki keterbatasan terutama dalam jumlah data yang digunakan relatif sedikit. Hal ini memang tidak dapat dihindari, mengingat Jakarta Islamic Index di Bursa Efek Indonesia membatasi 30 perusahaan syariah yang dapat masuk kedalam kelompok tersebut. Akan tetapi, saat ini sudah mulai dikenal adanya Daftar Efek Syariah yang memiliki cakupan yang lebih besar. Oleh karena itu daftar tersebut bisa dipilih untuk dijadikan obyek bagi penelitian selanjutnya agar data lebih banyak dan hasilnya lebih bisa menggambarkan keadaan indeks yang sebenarnya.

\section{Pustaka Acuan:}

Astuti, Rini Dwi, "Analisis Makro Kinerja Pasar Modal Dengan Pendekatan Error Correction Model (ECM)," Jurnal Ekonomi Pembangunan: Kajian Ekonomi Negara Berkembang, Vol. 6, No. 1, 2001.

Auliyah, Robiatul, dan Ardi Hamzah, “Analisis Karakteristik Perusahaan, Industri Dan Ekonomi Makro Terhadap Return Dan Beta Saham Syariah Di Bursa Efek Jakarta," Simposium Nasional Akuntansi IX, (Agustus, 2006).

Bafadal, Fadhal, AR, Yayasan Penyelenggara Penerjemah Al-Quran, Departemen Agama RI, Al-Quran Dan Terjemahaya, Jakarta: CV. Karya Insan Indonesia, 2004. Djalal, Nachrowi dan Hardius Usman, Pendekatan Popular dan Praktis Ekonometrika Untuk Analisis Ekonomi Dan Keuangan, Jakarta: Lembaga Penerbit Fakultas Ekonomi Universitas Indonesia, 2006.

Heliyani, “Analisis Pengaruh Variabel Ekonomi Makro Terhadap Return Saham Pada Industri Farmasi”, Jurnal STIE Haji Agus Salim Bukit Tinggi, Vol 2, No.1, 2007

Hidayat,Taufik, Buku Pintar Investasi Syariah, Jakarta: Mediakita, 2011.

HR, Muhamad Nafik, Bursa Efek dan Investasi Syariah, Jakarta: PT. Serambi Ilmu Semesta, 2009. 
Siti Sunayah, Zaini Ibrahim: Analisis Pengaruh Perubahan...

Huda, Nurul dan Mustafa Edwin Nasution, Current Issues Lembaga Keuangan Syariah, Jakarta: Kencana, 2009.

Media Group, 2008.

Huda, Nurul, dan Mohamad Heykal, Lembaga Keuangan Islam: Tinjauan Teoritis dan Praktis, Jakarta: Kencana, 2010.

Husein, Umar, Metode Penelitian Untuk Skripsi Dan Tesis, Jakarta: Rajawali Pres, 2009. Imronudin, "Pengaruh Kebijakan Moneter Terhadap Hubungan Model Tiga Faktor Dengan Return Saham, "Jurnal Benefit, Vol. 9, No. 2, 2005.

Kewal, Suramaya Suci, "Pengaruh Inflasi, Suku Bunga, Kurs, Dan Pertumbuhan Pdb Terhadap Indeks Harga Saham Gabungan," Jurnal Ekonomia, Vol 8, No. 1, April, 2012.

Muhamad, Dasar-Dasar Keuangan Syariah, Yogyakarta: Ekonosia Fakultas Ekonomi UII, 2014.

Nellis, Joseph G, dan David Parker, The Essence Of The Economy, Yogyakarta: Andi and Perason Education Asia Pte. Ltd, 2000.

Nurhayati, Sri dan Wasilah, Akuntansi Syariah di Indonesia, Jakarta: Salemba Empat, 2011.

Pasaribu, Rowland Bismark Fernando, dan Mikail Firdaus, "Pengaruh Variabel Ekonomi Makro Terhadap Indeks Saham Syariah Indonesia," Jurnal Ekonomi dan Bisnis, Vol 7, No. 2 (Juli 2013)

Puspopranoto, Sawaldjo, Keuangan Perbankan dan Pasar Keuangan: Konsep, Teori dan Realita Edisi I, Jakarta: Pustaka LP3ES Indonesia, 2004.

Rahardja, Prathama dan Mandala Manurung, Pengantar Ilmu Ekonomi: Mikroekonomi \& Makroekonomi, Jakarta: Lembaga Penerbit Fakultas Ekonomi Universitas Indonesia, 2008.

Rindjin, Ketut, Pengantar Perbankan Dan Lembaga Keuangan Bukan Bank, Jakarta: PT Gramedia Pustaka Utama, 2008.

Soemitra, Andri, Bank dan Lembaga Keuangan Syariah, Jakarta: Kencana, 2010.

Sukirno, Sadono, Pengantar Teori Makro Ekonomi. Edisi II, Jakarta: PT. Raja Grafindo, 2001. 
Islamiconomic: Jurnal Ekonomi Keuangan dan Bisnis Islam Vol.7 No.1 Januari - Juni 2016

Widoatmojo, Sawidji, Pasar Modal Indonesia: Pengantar \& Studi Kasus, Bogor: Ghalia Indonesia, 2009.

Winarno,Wing Wahyu, Analisis Ekonometrika dan Statistika dengan Eviews, Yogyakarta : UPP STIM YKPN, 2007.

www.bi.go.id

www.idx.go.id

www.telkom.co.id

\section{Catatan Akhir:}

${ }^{1}$ Muhamad, Dasar-Dasar Keuangan Syariah, (Yogyakarta: Ekonisia Fakultas Ekonomi UII, 2014), h. 2.

${ }^{2}$ Rowland Bismark Fernando Pasaribu dan Mikail Firdaus, "Pengaruh Variabel Ekonomi Makro Terhadap Indeks Saham Syariah Indonesia," Jurnal Ekonomi dan Bisnis, Vol 7, No. 2 (Juli 2013), h.117.

${ }^{3}$ Sawidji Widoatmojo, Pasar Modal Indonesia: Pengantar \& Studi Kasus, (Bogor: Ghalia Indonesia, 2009), h.8.

${ }^{4}$ Muhamad Nafik HR, Bursa Efek dan Investasi Syariah, (Jakarta: PT. Serambi Ilmu Semesta, 2009), h.177.

5 Sri Nurhayati dan Wasilah, Akuntansi Syariah..., h.346.

${ }_{7}^{6}$ Sri Nurhayati dan Wasilah, Akuntansi Syariah di Indonesia, (Jakarta: Salemba Empat, 2011), h.347.

7 Nurul Huda dan Mustafa Edwin Nasution, Investasi pada Pasar Modal Syariah, (Jakarta: Kencana Prenada Media Group, 2008), h. 58.

${ }^{8}$ Ketut Rindjin, Pengantar Perbankan Dan Lembaga Keuangan Bukan Bank, (Jakarta: PT Gramedia Pustaka Utama, 2008), h. 141.

${ }^{9}$ Nurul Huda dan Mustafa Edwin Nasution, Current Issues Lembaga Keuangan Syariah, (Jakarta: Kencana, 2009), h.125

${ }^{10}$ Fadhal, AR, Bafadal, Yayasan Penyelenggara Penerjemah Al-Quran, Departemen Agama RI, Al-Quran Dan Terjemahaya, (Jakarta: CV. Karya Insan Indonesia, 2004).

11 Fadhal, AR, Bafadal, Yayasan Penyelenggara Penerjemah Al-Quran, Departemen Agama RI, Al-Quran Dan Terjemahaya, (Jakarta: CV. Karya Insan Indonesia, 2004).

12 Joseph G Nellis dan David Parker, The Essence Of The Economy, (Yogyakarta: Andi and Perason Education Asia Pte. Ltd, 2000), h. 216.

${ }^{13}$ Sadono Sukirno, Pengantar Teori Makro Ekonomi. Edisi II, (Jakarta: PT. Raja Grafindo, 2001), h. 197.

${ }^{14}$ Faisal Basri dan Haris Munandar, Dasar-Dasar Ekonomi Internasional ..., h. 29.

${ }^{15}$ Fadhal, AR, Bafadal, Yayasan Penyelenggara Penerjemah Al-Quran, Departemen Agama RI, Al-Quran Dan Terjemahaya, (Jakarta: CV. Karya Insan Indonesia, 2004).

${ }^{16}$ Prathama Rahardja dan Mandala Manurung, Pengantar Ilmu Ekonomi: Mikroekonomi \& Makroekonomi, (Jakarta: Lembaga Penerbit Fakultas Ekonomi Universitas Indonesia, 2008), h.359.

${ }_{17}^{17}$ Rowland Bismark Fernando Pasaribu dan Mikail Firdaus, Jurnal Ekonomi dan Bisnis..., h.120.

${ }^{18}$ Fadhal, AR, Bafadal, Yayasan Penyelenggara Penerjemah Al-Quran, Departemen Agama RI, Al-Quran Dan Terjemahaya, (Jakarta: Cv Karya Insan Indonesia,2004)

${ }^{19}$ Sawaldjo Puspopranoto, Keuangan Perbankan dan Pasar Keuangan: Konsep, Teori dan Realita Edisi I. (Jakarta: Puataka LP3ES Indonesia, 2004), h. 69.

${ }^{20}$ Taufik Hidayat, Buku Pintar Investasi ..., h. 23.

${ }^{21}$ Fadhal, AR, Bafadal, Yayasan Penyelenggara Penerjemah Al-Quran, Departemen Agama RI, Al-Quran Dan Terjemahaya, (Jakarta: Cv Karya Insan Indonesia,2004)

${ }^{22}$ Nurul Huda dan Mohamad Heykal, Lembaga Keuangan Islam... h. 191

${ }^{23}$ Taufik Hidayat, Buku Pintar Investasi ..., h. 26.

${ }^{24}$ Andri Soemitra, Bank dan Lembaga Keuangan Syariah, (Jakarta: Kencana, 2010), h. 110.

${ }^{25}$ Suramaya Suci Kewal, "Pengaruh Inflasi, Suku Bunga, Kurs, Dan Pertumbuhan Pdb Terhadap Indeks Harga Saham Gabungan,” Jurnal Ekonomia, Vol 8, No. 1 (April, 2012), h.54. 
${ }^{26}$ Heliyani, "Analisis Pengaruh Variabel Ekonomi Makro Terhadap Return Saham Pada Industri Farmasi”, Jurnal STIE Haji Agus Salim Bukit Tinggi, Vol 2, No.1, 2007.

27 Rini Dwi Astuti, "Analisis Makro Kinerja Pasar Modal Dengan Pendekatan Error Correction Model (ECM), ” Jurnal Ekonomi Pembangunan: Kajian Ekonomi Negara Berkembang, Vol. 6, No. 1, 2001.

28 Imronudin, "Pengaruh Kebijakan Moneter Terhadap Hubungan Model Tiga Faktor Dengan Return Saham," Jurnal Benefit, Vol. 9, No. 2, 2005.

${ }^{29}$ Robiatul Auliyah dan Ardi Hamzah, "Analisis Karakteristik Perusahaan, Industri Dan Ekonomi Makro Terhadap Return Dan Beta Saham Syariah Di Bursa Efek Jakarta," Simposium Nasional Akuntansi IX, (Agustus, 2006).

${ }^{30}$ Umar Husein, Metode Penelitian Untuk Skripsi Dan Tesis, (Jakarta: Rajawali Pres, 2009), h. 143

${ }^{31}$ Wing Wahyu Winarno, Analisis Ekonometrika dan Statistika ... h, 5.25

${ }^{32}$ Wing Wahyu Winarno, Analisis Ekonometrika dan Statistika dengan Eviews, (Yogyakarta: UPP STIM YKPN, 2007), h. 5.1

${ }^{33}$ Nachrowi Djalal dan Hardius Usman, Pendekatan Popular dan Praktis Ekonometrika Untuk Analisis Ekonomi Dan Keuangan, (Jakarta: Lembaga Penerbit Fakultas Ekonomi Universitas Indonesia, 2006), h. 21 